\title{
THE BUCK STOPS ... WHERE, EXACTLY? ON OUTSOURCING AND LIABILITY TOWARDS THIRD PARTIES
}

\author{
Daleen Millard \\ Blur LLB LLM LLD \\ Professor in Private Law \\ University of Johannesburg \\ Monray Marsellus Botha \\ BLC LLB LLM BCom(Hons) MCom \\ Senior lecturer in Mercantile Law \\ North-West University, Potchefstroom
}

\section{SUMMARY}

Modern-day commerce forces services providers to make use of outsourcing. Regardless of whether outsourcing is used for bona fide reasons such as to provide a better product at a better price or whether the outsourcer needs to dispose of troublesome employees or to limit his liabilities towards third parties, it is suggested that outsourcers should consider a number of issues when outsourcing. Conversely, in considering a liability issue, a court may also measure the conduct of a particular outsourcer in order to evaluate whether such outsourcer has acted bona fide and responsibly. Little research is available on outsourcing and the affect thereof on thirdparty liability. Although the LRA and CPA contains provisions on certain general aspects, it may be that industry-specific legislation regulates specific outsourcing agreements. This article attempts to reconcile these seemingly disjointed topics. The authors conclude that sound legal advice should be sought before outsourcing is considered in order to avoid possible problems associated with it as well as liabilityrelated pitfalls.

\section{INTRODUCTION}

Employers may outsource functions increasingly in order to avoid liability, costly lawsuits and the payment of exorbitant insurance premiums. Or a bona fide employer may simply outsource certain non-core functions in order to channel more capital to his core activities. ${ }^{1}$

\footnotetext{
Van Niekerk, Christianson, McGregor, Smit and Van Eck Law@work (2012) 325 state "companies are increasingly restructuring to focus on what is termed 'core business', and many services and functions once provided 'in-house' are being outsourced, to be provided
} 
Basically, outsourcing "involves the putting out to tender of certain services for a fee" where the "contractor performs the outsourced services and in return a fee is paid for its services by the employer". ${ }^{2}$ In addition, an outsourcing transaction is usually for a fixed period of time and at the end of that term the transaction again goes out to tender and the existing contractor could lose the contract to another contractor."

The question is, however, whether outsourcing has not perhaps become a means of avoiding liability for unsound practices that may endanger members of the public. In addition, should employers not perhaps be held liable regardless of having outsourced a particular function where such outsourcing was done in an irresponsible manner? When one starts to unpick the law that regulates outsourcing from a risk point of view it transpires that the legal position is rather complicated. An example is necessary: Shopping centre A is the property of B. B's main business is the letting of office and retail space in centre $A$ and in other industrial properties. $\mathrm{B}$ contracted with $\mathrm{C}$ for the security of the entire centre. In addition, all cleaning services are outsourced to D. Company $E$ has a contract with $B$ for the collection and delivery of shopping trolleys. For a number of months customers have complained to the management of $B$ of damage to and theft of their vehicles. This ranges from scratches presumably inflicted by trolley collectors to broken locks. B is convinced that the outsourcing of services to $\mathrm{C}, \mathrm{D}$ and $\mathrm{E}$ resulted in their not being responsible for any damage caused to customers' vehicles.

But is it really that simple? Who bears the risk for the damage caused to third parties? What is the possible basis for liability? Is it strict liability in the form of either vicarious liability or liability as envisaged by the Consumer

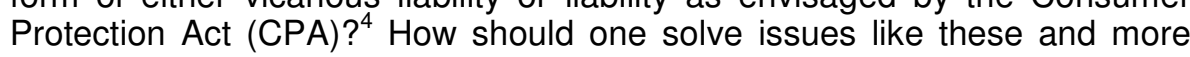
importantly, how should outsourcing agreements ideally be constructed so that third parties who incurred losses are not left high and dry?

For instance, in Charter Hi $v$ Minister of Transport ${ }^{5}$ the appellant alleged that an aircraft accident was caused as a result of the negligence of the flight inspector who conducted an instrument test on the pilot. The flight inspector passed away and the applicant sought to sue the Minister of Transport for damages on the basis of vicarious liability. Also, in Chartaprops 16 (Pty) Ltd $v$ Silberman $^{6}$ the court considered a matter closely related to vicarious liability, namely whether an outsourcer (mandator) could be held liable for the actions of the outsourcee (mandatary) regardless of the outsourcing

by independent service providers engaged on a commercial basis. In many of these instances, one employer transfers businesses or parts of businesses to another, a situation where commercial interests in greater flexibility and profitability are often in conflict with employee interests in work security".

2 NEHAWU v University of Cape Town [2000] 7 BLLR 803 (LC) par 30.

3 It can thus be said that an enterprise "unbundles itself" by contracting with other entities to perform some of the tasks previously performed by its own employees (see Biggs "The Application of Section 197 of the Labour Relations Act in an Outsourcing Context (Part 2)" 2009 Obiter 656666

68 of 2008.

[2011] ZASCA 89.

2009 (1) SA 265 (SCA). 
contract because of a higher degree of care which was expected of the outsourcer.

This article attempts to reconcile a number of seemingly disjointed topics but a closer look reveals how these elements in fact relate to the issue at hand. In practice, a lawyer will first have to consider the Labour Relations Act (LRA) ${ }^{7}$ and the CPA as two statutes of general application. The LRA is relevant to determine whether a person is an employee for purposes of vicarious liability as well as to establish whether outsourcing falls within the ambit of transfer of business in terms of section 197 of the LRA. The CPA introduces strict liability and contains provisions pertaining to disclaimers which might be relevant to outsourcing and liability, depending on the nature of the outsourced activities.

Little research is available on outsourcing and the effect thereof on thirdparty liability. Although the LRA and CPA contains provisions on certain general aspects, it may be that industry-specific legislation regulates specific outsourcing agreements. This article also singles out a number of industries as examples how risks are transferred and managed but these examples do not constitute a numerous clausus and practitioners are advised to scrutinize legislation before coming to a final solution.

Finally this article advocates responsible outsourcing and proposes that all outsourcing contracts should comply with certain minimum standards in order to avoid a situation where third parties suffer harm and are left without redress. The role of liability insurance is also considered in this context.

\section{VICARIOUS LIABILITY}

Vicarious liability is "the strict liability of one person for the delict of another". 8 Theories such as the employer's fault in selecting the employee, the interestand-profit theory, the solvency theory, and the risk or danger theory attempt to explain the rationale and basis of vicarious liability. ${ }^{9}$ Where ordinarily a wrongdoer has to act with fault in order to be liable, ${ }^{10}$ vicarious liability is a form of strict liability which means that someone is liable to another regardless of whether they had acted with fault. Instances of strict liability are the exception to the rule and stem mainly from modern legislation (such as the CPA $)^{11}$ or common-law actions of Roman origin. ${ }^{12}$ In the example in paragraph 1 above, one will therefore have to establish who the wrongdoers were employees or not. Strict liability has been applied for quite some time (and has been well-established) to the employment relationship where an employer may be held vicariously liable for delicts committed by

66 of 1995.

Neethling-Potgieter-Visser Law of Delict (2009) 365 (authors' own emphasis).

For a detailed discussion, see Potgieter "Preliminary Thoughts on Whether Vicarious Liability Should be Extended to Parent-child Relationship" 2011 Obiter 189 191-192. See also Neethling-Potgieter-Visser Law of Delict 365-366.

10 Neethling-Potgieter-Visser Law of Delict 329.

11 Botha and Joubert "Does the Consumer Protection Act 68 of 2008 Provide for Strict Liability? - A Comparative Analysis" 2011 THRHR 305-319.

12 Van der Walt and Midgley Principles of Delict (2005) par 28. 
employees. ${ }^{13}$ In order for an employer to be vicariously liable there must be an employment relationship existing at the time when the employee committed the delict and the employee must have acted within the scope of his employment. ${ }^{14}$ Therefore, in order to hold an employer vicariously liable it must first be established whether such a person is an employee.

\section{Who is an employee?}

Section 213 LRA provides that an employee is:

"(a) any person, excluding an independent contractor, who works for any person or for the State and who receives, or is entitled to receive, any remuneration; (b) any other person who in any manner assists in carrying on or conducting the business of the employer."

Labour legislation has expanded the definition of "employee" beyond the common-law definition of someone who places his or her labour potential under the control of another person, in order to extend protection to as many persons as possible. The definitions of "employee" in the LRA, the Basic Conditions of Employment Act (BCEA), ${ }^{15}$ the Compensation for Occupational Injuries and Diseases Act (COIDA), ${ }^{16}$ the Unemployment Insurance Act (UIA) ${ }^{17}$ and the Skills Development Act (SDA), ${ }^{18}$ expressly exclude an independent contractor from the definition of "employee". Our law has always distinguished between employees and independent contractors. ${ }^{19}$ Our courts have listed the main differences between employees and independent contractors on several occasions. ${ }^{20}$ These differences are important because the legal rights of each category vary considerably. Employees, for example, receive protection regarding unfair dismissal, unfair labour practices, unfair discrimination etcetera. ${ }^{21}$ However, Niselow, is the

13 One of the earliest examples of liability of an employer for delicts of his employees is found in Feldman (Pty) Ltd v Mall 1945 AD 733.

14390.

1575 of 1997.

16130 of 1993

1763 of 2001.

1897 of 1998.

19 See Langley Fox Building Partnership (Pty) Ltd v De Valance 1991 (1) SA 1 (A) 8; Smit v Workmen's Compensation Commissioner 1979 (1) SA 51 (A) where the court listed factors that are indicative of an employment relationship as well as Midway Two Engineering \& Construction Services v Transnet Bpk 1998 (3) SA 17 (SCA) 23). See also Smit and Botha "Is the Protected Disclosures Act 26 of 2000 Applicable to Members of Parliament? 2011 TSAR 815-829, on whether members of parliament were employees and employers for purposes of the Protected Disclosures Act 26 of 2000.

20 See eg, SA Broadcasting Corporation v McKenzie [1999] 1 BLLR 1 (LAC); Niselow v Liberty Life Association of Africa Ltd 1998 ILJ 752 (SCA); Smit v Workmen's Compensation Commissioner (supra); and South African Master Dental Technicians Association v Dental Association of South Africa 1970 (3) SA 733 (A).

21 The LRA gives effect to the right to fair labour practices in that employees have the right not to be unfairly dismissed or subjected to unfair labour practices. S 186(2) of the LRA provides for the definition of "unfair labour practices". S 185 of the LRA provides that every employee has the right not to be unfairly dismissed. In s 186(1) the LRA also provides for a definition of dismissal of an employee. S 188 requires that the dismissal of en employee must not only be for a fair reason but also be effected in accordance with a fair procedure. $S$ 187 , on the other hand, provides for dismissals that are "automatically unfair", where the 
only case that dealt with the substantive issue of who was an employee. The court, however, dealt with the definition of "employee" in terms of the Labour Relations Act 28 of 1956. The court in the Niselow case held than an employee at common law undertook to render a personal service to an employer. ${ }^{22}$ The court further held that regardless of the second part of the definition ("any other person whomsoever who in any manner assists in the carrying on or conducting of the business of an employer") it also did not bring the individual in that case within the scope of the definition. The court based this on distinguishing a contract of work and a contract of service. Consequently, the appellant in that case, who was an agent contracted to canvas-insurance business for the respondent, was carrying on and conducting his own business rather than assisting in the carrying on or conducting of the business of the respondent. In the labour appeal court the court noted, however, that the supreme court of appeal "did not have the benefit of argument on the second part of the definition of 'employee'. The court's finding was primarily based on an application of the first part of the definition ('any person who is employed by or working for an employer and receiving or entitled to receive any remuneration ...') to the facts of the case". ${ }^{23}$ In the Niselow case the supreme court of appeal placed specific emphasis on the three aspects in reaching its decision that the agent was an independent contractor and not an employee: First, the agreement specifically provided that the continuance of the agreement depended on the appellant maintaining his status as an agent (that is, maintain a satisfactory standard of knowledge and competence etcetera). That means that the appellant was therefore obliged to produce a certain result in order to keep the contract alive, secondly, the appellant's remuneration was to be commission on contracts effected through him and he was thus entitled to remuneration for the result of his labour and not the time spent by him canvassing for contracts, and thirdly, it was not prescribed when, how and where the required result was to be achieved. ${ }^{24}$

The Code of Good Practice: Who is an Employee? (Code of Good Practice) provides guidelines for determining whether persons are employees to ensure that they are protected under labour law and are not deprived of these protections by dishonest contracting arrangements. The courts, in recent years, were faced with the issue in Discovery Health Ltd $v$ $C_{C M A}{ }^{25}$ State Information Technology Agency (Pty) Ltd $v C C M A^{26}$ and

reason for dismissal is sufficient to declare it unfair and there is no justification for the employer for such a dismissal. S 188 provides for dismissals that are not automatically unfair. These dismissals would be unfair where the employer fails to prove that the dismissal is for a fair reason related to either the employee's conduct or capacity, or based on the employer's operational requirements. In addition to substantive fairness the employer must also prove that a fair procedure was followed. These protections are, however, not granted if a person is an independent contractor because the LRA (as well as other labour legislation) protects only a person with when he or she is an employee. The Employment Equity Act (EEA) is different to the extent that is also protects job applicants against 22 7531. intion even though they are not employees.

23 Par 30.

24 775E-776A.

252008 ILJ 1480 (LC).

262008 ILJ 2234 (LAC). 
Kylie $v \mathrm{CCM} \mathrm{A}^{27}$ to determine the identity of the employee and to determine to what extent individual workers were entitled to labour protection. ${ }^{28}$ Both the LRA and BCEA, were amended in 2002 to include the rebuttable presumption of employment in order to assist persons who claim to be employees rather than independent contractors. These factors are the following, namely: the manner in which the person works is subject to the control or direction of another person; the person's hours of work are subject to the control or direction of another person; in the case of a person who works for an organization, the person forms part of that organization; the person has worked for that person for an average of at least 40 hours per month over the last three months; the person is economically dependent on the other person for whom he or she works or renders services; the person is provided with tools of trade or work equipment by the other person; or the person works only for or renders service to one person. Van Niekerk AJ stated in Discovery Health Limited states that

"The protection against unfair labour practices established by $s$ 23(1) of the Constitution $^{29}$ is not dependent on a contract of employment. Protection extends potentially to other contracts, relationships and arrangements in terms of [which] a person performs work or provides personal services to another. The line between performing work 'akin to employment' and the provision of services as part of a business is a matter regulated by the definition of 'employee' in s 213 of the LRA."

In the Kylie case Cheadle AJ for example stated that not everyone who works is a worker for purposes of section 23 and that it does not apply to persons who own and work for their own business like independent contractors, partners and the self-employed. It also does not apply to judges or cabinet ministers. ${ }^{31}$ In context of section $23(1)$ of the Constitution Cheadle ${ }^{32}$ has argued that there had to rather be an emphasis placed on the words "labour practices" than "everyone" and that labour practices were "practices that arose from the relationship between workers, employers and their respective organizations. Accordingly, the right to fair labour practices ought not to be read as extending the class of persons beyond those envisaged by the section as a whole". Whether a person falls within the definition of an employee is not just important from a labour-protection point of view but also from a vicarious liability perspective and all the factors mentioned above also assist with the enquiry into vicarious liability.

\section{Scope of employment}

In addition to being an employee, the employee must have acted in the scope of his employment for the employer to be vicariously liable. Parties to

2008 ILJ 1918 (LC)

28 See Le Roux "The Meaning of 'Worker' and the Road Towards Diversification: Reflecting on Discovery, SITA and 'Kylie' 200930 ILJ 49, for a detailed discussion of these cases.

29 S 23(1) of the Constitution of 1996 provides that "everyone has the right to fair labour practices".

30 Par 41.

31 Par 54.

32 "Labour Relations" in Cheadle, Davis and Haysom South African Constitutional Law: The Bill of Rights (2006) 18-3. 
a contract of mandate can therefore never be sued on the basis of vicarious liability. From a risk perspective, it is therefore an attractive option to outsource a portion of an operation, which poses a high risk to an employer. For instance, if $B$, the owners of shopping mall, $A$ in the example above were the employer of the cleaners in the mall, they would be vicariously liable for the culpable actions of the cleaners, provided that there is a nexus between the employee's wrongful, culpable, damage-causing conduct and the relationship between him and his employer. ${ }^{33}$

What is inside or outside the scope of employment has been the subject of some debate. In Mkhize v Martens, ${ }^{34}$ for example, it was stated that "the master is answerable for the torts of his servant committed in the course of his employment, bearing in mind that an act done by the servant solely for his own interest and purposes and outside his authority is not done in the course of his employment, even though it may have been during his employment". ${ }^{35}$ There is evidently no general rule when it comes to the question whether the act of the employee falls inside or outside the scope of employment. It is largely dependent on the facts of each case. ${ }^{36}$ To deal with this difficulty, the courts have developed certain sub-rules. These include the so-called deviation cases, ${ }^{37}$ "intentional misconduct (wilful wrongdoing) where the employee did not act in furtherance of the employer's business" and unauthorized transport of passengers in the vehicles of the employer. ${ }^{38}$ In the past, deviation cases were the focus of most cases dealing with vicarious liability and the Supreme Court of Appeal in Minister of Safety \& Security $v$ Jordaan $t / a$ Andre Jordaan Transport $t^{39}$ held that

"[i]n each case, whether the employer is to be held liable or not must depend on the nature and extent of the deviation. Once the deviation is such that it cannot be reasonably held that the employee is still exercising the functions to which he was appointed or still carrying out some instruction of his employer, the latter will cease to be liable. Whether that stage has been reached is essentially a question of degree".

The court then added that a close consideration of the facts would be taken into account on a case-by-case basis. ${ }^{40}$

In 2003 and 2004 two very important judgments with regard to liability of employers emerged from the Labour Court and the High Court respectively. These cases were Ntsabo $v$ Real Security $\mathrm{CC}^{41}$ and Grobler v Naspers.

33 Wicke "Vicarious Liability: Not Simply a Matter of Legal Policy" 1998 Stell LR 2130.

1914 AD 382394.

35 See also Boland Bank Bpk v Bellville Munisipaliteit 1981 (2) SA 437(C) 444-445 in this regard.

36 Wicke 1998 Stell LR 30; Calitz "Vicarious Liability of Employers: Reconsidering Risk as the Basis for Liability" 2005 TSAR 215218.

37 Wicke 1998 Stell LR 31. In Feldman (Pty) Ltd $v$ Mall (supra) the court also dealt with deviation cases and said that it was a question of degree with regard to space and time when determining if the act of an employee fell within scope of employment or not.

38 Calitz 2005 TSAR 218.

392000 ILJ 2585 2588D-F.

40 See also Viljoen $v$ Smith (supra) and African Guarantee and Indemnity Co Ltd v Minister of Justice 1959 (2) SA 437 (A) with regard to this matter.

41 (2003) 24 ILJ 2341 (LC).

42 This case was taken on appeal as Media 24 Ltd v Grobler 2005 (6) SA 328 (SCA). 
Ntsabo dealt with the statutory liability of an employer for unfair discrimination or harassment ${ }^{43}$ of employees against other employees, whereas Grobler dealt with an employer's vicarious liability for sexual harassment by another of its employees. The facts in these cases were not similar but and illustrated different approaches to determine the liability of the employer. ${ }^{44}$ It has clearly been established that whether an employee acts within the scope of his employment or not is a subjective-objective test. $^{45}$ In Minister of Police $v$ Rabie, ${ }^{46}$ the court explained the so-called standard test ${ }^{47}$ for vicarious liability as follows:

"It seems clear that an act done by a servant solely for his own interests and purposes, although occasioned by his employment, may fall outside the course or scope of his employment, and that in deciding whether an act by the servant does fall, some reference is to be made to the servant's intention [...] The test is in this regard subjective. On the other hand, if there is nevertheless a sufficiently close link between the servant's acts for his own interests and purposes and the business of his master, the master may yet be liable. This is an objective test."

In 2005 the Constitutional Court in $K v$ Minister of Safety \& Security ${ }^{48}$ again examined the sufficiently-close-connection test (as mentioned in Rabie). The Supreme Court of Appeal dismissed the appeal due to the fact that the employees' acts were outside the course and scope of their employment and that the question in deviation cases was "whether the deviation was of such a degree that it can be said that in doing what he or she did the employee was still exercising functions to which he or she had been appointed or was still carrying out some instruction of his or her employer". ${ }^{49}$ It is, however, possible for an employee to act within the course and scope of his employment and outside of it at the same time. This "dual

43 Etsebeth "The Growing Expansion of Vicarious Liability in the Information Age (Part 2)" 2006 TSAR 752 points out that it is "evident that companies can be held vicariously liable in the case of the inappropriate use/abuse of corporate internet and email facilities, in the form of harassment, discrimination, defamation (resulting from ill-conceived wording in an email), copyright infringement (where the employee carelessly downloads and disseminates copyright material and software), criminal liability (if child pornography is downloaded) and even liability under the law of contract (where an employee inadvertently forms a contract through an email)".

44 The Grobler case included sexual harassment, applied common-law remedies rather than statutory remedies, and used the High Court to enforce these remedies, whereas Ntsabo utilized the statutory remedies and used the Labour Court to enforce these remedies. In Ntsabo the court found that the supervisor's conduct was a contravention of section 60 of the EEA and that it amounted to sexual harassment and constituted unfair discrimination, which was prohibited in terms of s 6(3) of that Act. Damages were awarded to Ntsabo for breach of this duty. In Grobler the court held that the employer was vicariously liable for the supervisor sexually harassing Mrs Grobler. See for detailed discussion Smit and Van der Nest "When Sisters are Doing it for Themselves: Sexual Harassment Claims in the Workplace" 2004 TSAR 520-543; Le Roux "Sexual Harassment in the Workplace: Reflecting on Grobler v Naspers" 2004 ILJ 1897-1900; and Whitcher "Two Roads to an Employer's Vicarious Liability for Sexual Harassment: S Grobler v Naspers Bpk en 'n Ander and Ntsabo $v$ Real Security CC" 2004 ILJ 1907-1924. Neethling-Potgieter-Visser Law of Delict 368.

$46 \quad 1986$ (1) SA 117 (A) 134.

47 Neethling-Potgieter-Visser Law of Delict 368-369.

48 [2005] ZACC 8; 2005 (6) SA 419 (CC); 20059 BCLR 835 (CC).

49 K v Minister of Safety \& Security 200526 ILJ 681 (SCA) par 4. 


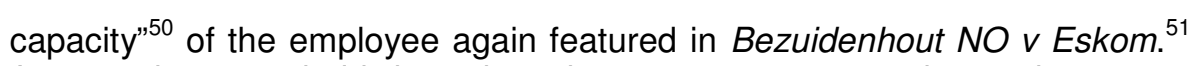
In casu the court held that when there was an express instruction not to transport passengers while the employee was entrusted with driving the employer's vehicle and the passenger was then injured, the employer was not vicariously liable because the employee did not act within the course and scope of employment. This illustrates that an employer will not be vicariously liable for all actions of employees. ${ }^{52}$ An employer will, however, not escape liability merely because the conduct was "fraudulent, ${ }^{53}$ unauthorised and undertaken for the employee's own interest". ${ }^{54}$ As long as a "sufficiently close link between the employee's conduct and what the employer authorises to perform is established, the employer is vicariously liable". ${ }^{5}$

To bring these principles in context with the dilemma of liability for damage caused to third parties and outsourcing, the next two recent examples from case law will be discussed.

\section{Charter $\mathrm{Hi} v$ Minister of Transport ${ }^{56}$ Chartaprops 16 (Pty) Ltd v Silberman ${ }^{57}$}

and

In Charter $\mathrm{Hi}$ the legal questions in casu were whether Mr Grinstead, a flight inspector, had acted negligently, whether his negligence had caused the accident, and whether the Minister was vicariously liable as a result. ${ }^{58}$

The judgment on negligence and causation is a protracted one which will not be repeated. Suffice to say that according to the court, it was in fact anybody's guess what had happened shortly before the accident. On the evidence, there was no negligence on behalf of Mr Grinstead and even if

50 Le Roux "Vicarious Liability: Revisiting an Old Acquaintance" 2003 ILJ 1879.

51200324 ILJ 1084 (SCA).

52 See Costa da Oura Restaurant (Pty) Ltd t/a Umdloti Bush Tavern v Reddy 200324 ILJ 1337 (SCA), where an employee (a barman) assaulted a patron because he was upset about the quality of service and made comments about it. The barman later followed the patron outside and assaulted him. The court held that the employee's conduct was a personal act of aggression that was neither in furtherance of the employer's interest nor under his authority.

53 See Minister of Finance $v$ Gore 2007 (1) SA 111 (SCA), where the court held that the Minister of Finance was vicariously liable for the employees' deliberate dishonest actions (fraud) in the tender process. The court held the Minister was liable "if objectively seen, there is a sufficiently close link between the self-directed conduct and the employer's business" (par 28); see also Neethling and Potgieter "Middellike Aanspreeklikheid vir 'n Opsetlike Delik" 2007 TSAR 616 for discussion of the Gore-case.

54 Smit and Van der Nest 2004 TSAR 536.

55 Ibid.

56 Supra 89.

57 Supra.

58 On 13 December 1996 an aircraft accident occurred North of Cape Town. Mr Jonathan Grant was the pilot of a twin-engine turbo-prop Beechcraft King Air C90 and at the time he was being examined by Mr Ray Grinstead, an official flight examiner, for competency at instrument flying (par 1). Mr Grinstead was a designated official flight examiner of DOFE and was as such appointed by the Commissioner for Civil Aviation, who fell under the auspices of the Minister of Transport. The pilot, the examiner and a passenger were killed in the accident and the appellants, who had a financial interest in the aircraft, sued the Minister for the loss that resulted from the destruction of the aircraft (par 1). 
there was negligence, the appellants could not prove that that had caused the accident.

Of importance to the present discussion is the court's observations on vicarious liability. In fact, if there was no delict, the question of vicarious liability fell away but the court nevertheless found it important to deal with this matter, thereby reiterating that in order for an employer to be vicariously liable for the acts of his employee, it should first and foremost be clear that there should have been an employer-employee relationship. ${ }^{59}$ The court in casu examined the nature of the relationship between Mr Grinstead and the Department of Transport and found that official flight examiners were not employees of the Department of Transport and were not paid by the Department. Upon being designated an official flight examiner, the Department published the name and an examinee could then chose an examiner from the list and paid him or her ${ }^{60}$ The court remarked that there was clearly no employer-employee relationship between Mr Grinstead and the Department of Transport and that there could therefore be no vicarious liability. In casu the appellants had not only failed to prove negligence but had also failed to establish that there was an employment relationship between the flight inspector and the Department of Transport. Therefore the appeal was dismissed with costs.

This case illustrates that outsourcing is often done because an institution (for whatever reason) no longer has the capacity to perform a particular function. Here, the function of flight inspectors was outsourced as a matter of policy. This policy includes identifying qualified inspectors in different areas and issuing an official list with the names of these inspectors. At no particular time is there a written agreement between the Minister and any of these inspectors, but the nature of the aviation industry is such that the inspectors are also subject to the Aviation $\mathrm{Act}^{61}$ and should they fail to comply with the requirements applicable to them personally, they will no longer qualify to appear on the official list. The Aviation Act in fact takes care of the standards that are required in the industry and provided that the CAA meticulously records the details of all flight inspectors and follows up on their personal compliance, the minimum standards that are adhered to and as well as that the Minister cannot be held liable. Although this case happens to deal with aviation it is submitted that the same principles may apply in a similar, highly regulated industry.

In Chartaprops 16 (Pty) Ltd $v$ Silberman ${ }^{62}$ the respondent (Mrs Silberman) slipped on a pool of slippery substance while she visited a shopping mall in Johannesburg and injured herself. Chartaprops (the first appellant) as the owner of the mall contracted Advanced Cleaning (the second appellant) to clean the floors of the mall. The respondent instituted action against both Chartaprops and Advanced Cleaning. The High Court found that Chartaprops and Advanced Cleaning were jointly and severally liable to Mrs Silberman as the employees of Advanced Cleaning failed to take reasonable steps to detect and remove the hazard. The cleaning system was

59 Neethling-Potgieter-Visser Law of Delict 366.

60 Par 5.

6174 of 1962.

62 Supra. 
accordingly not sufficiently adequate to detect and remove spillage as soon as reasonably possible and therefore Advanced Cleaning was negligent. In addition the court found that the first appellant was vicariously liable for the negligence of Advanced Cleaning. ${ }^{63}$

On appeal, the majority (per Ponnan JA with Scott and Maya JJA and Leach AJA concurring) reiterated that the general rule in our law is that a principal is not liable for the wrongs committed by an independent contractor or its employees and that they disagreed with the judgment of Nugent $\mathrm{JA}{ }^{64}$ Furthermore, the concept of non-delegable duty (where a principal will indeed be liable for the negligence of an independent contractor) has been the subject of debate in foreign jurisdictions. Such a duty has been described as "a special duty or duty to see that care is taken". Apparently this duty would "outflank the general principal that a defendant is not vicariously responsible for the negligence of an independent contractor where the causative agent of the negligence relied on was not an employee of the defendant but an independent contractor". ${ }^{65}$

63 Par 4

64 Par 27-28. Nugent JA (in the minority judgment) was of the view that the court a quo was incorrect in holding Chartaprops vicariously liable for the negligence on the part of Advanced Cleaning. It is well established that the contract of mandate, involving an independent contract, does not found vicarious liability. Nugent JA states: "A defendant might nonetheless be liable for harm that arises from negligent conduct on the part of an independent contractor but where that occurs the liability does not arise vicariously. It arises instead from breach of the defendant's own duty (I use that term to mean the obligation that arises when the reasonable possibility of injury ought to be foreseen in accordance with the classic test for negligence articulated in Kruger $v$ Coetzee). It will arise where that duty that is cast upon the defendant to take steps to guard against harm is one that is capable of being discharged only if the steps that are required to guard against the harm are actually taken. The duty that is cast upon a defendant in those circumstances has been described (in the context of English law) as a duty that is not capable of being delegated: "the performance of the duties, but not the responsibility for that performance, can be delegated to another'. Or as it has been expressed on another occasion it is 'a duty not merely to take care, but a duty to provide that care is taken' so that if care is not taken the duty is breached." According to Nugent JA, a higher degree of care should be applied where a person is in control of a shopping mall. In addition, the reasonable person in control of a shopping mall would "clearly foresee that spillages might occur in the passages and cause harm if they are permitted to remain, and would take reasonable steps to guard against harm occurring. The duty to take reasonable steps is not sufficiently discharged by the mere appointment of an apparently competent cleaning service. It is also reasonable to expect that a person in control of a shopping mall will ensure that reasonable precautions are taken to keep the floors safe and is therefore liable if such precautions are not taken by the person who is appointed to do so. Not only should an adequate system be in place but such system must be properly implemented. As Chartaprops failed to ensure that reasonable precautions were taken they are liable for the consequent damages. Nugent JA further held that Advanced Cleaning or its employees did not owe a legal duty towards the public to take reasonable steps to keep the floors safe. Therefore, "any omission to do so on their part is not actionable", with the result that Advanced Cleaning is not liable for damages whether it be on the basis of vicarious liability for any omission by its employees or directly for an omission on its part. ${ }^{64}$ The judge dismissed Chartaprops's appeal and upheld Advanced Cleaning's appeal.

65 Par 29. This special duty or duty of care is contentious. Neethling-Potgieter-Visser Law of Delict 152-153 holds as follows: An even more important reason to reject the application of the duty of care in our law is that in its traditional form it is unnecessary and a roundabout way of establishing what may be established directly by means of the reasonable person test for negligence, ie, whether the reasonable person would have foreseen and guarded against damage. Moreover, the use of the duty-of-care doctrine may confuse the test for 
The court remarked that the principles pertaining to negligence already took proper account of the presence of abnormally high risks and special vulnerabilities. Where those features are present "our law expects greater vigilance from a defendant to prevent the risk of harm from materialising, for that according to our law is what a reasonable person in the position of the defendant would do". ${ }^{66}$ Therefore, in such circumstances, a court's response "should not be to impose strict liability or to resort to a distinguished form of vicarious liability but rather insist on a higher standard of care". The correct approach to liability of a principal for the negligence of an independent contractor "is to apply the fundamental rule of our law that obliges a person to exercise that degree of care that the circumstances demand." ${ }^{67}$ The majority added that not only did Chartaprops contract with a responsible cleaning service but also exercised a higher degree of care because its centre manager consulted with the cleaning supervisor every morning and personally inspected the floors of the shopping mall on a regular basis to ensure that it had been properly cleaned. ${ }^{68}$ The court added that if there were any spillages the supervisor ensured immediate removal. Chartaprops therefore did "all that a reasonable person could do towards seeing that the floors of the shopping mall were safe." ${ }^{\prime \prime 9}$ In addition, neither the terms of Chartaprops's engagement with Advance Cleaning, nor the terms of its contract, served to discharge Chartaprops from its legal duty to persons who were strangers to those contracts. The duty of care is discharged by the appointment of a competent contractor, which was done by Chartaprops. Chartaprops had no means of knowing that the work of Advanced Cleaning would be defective and was obliged to take no more than reasonable steps against foreseeable harm to the public. ${ }^{70}$ The majority of the court held that the High Court erred in holding Chartaprops liable and the appeal of Chartaprops was accordingly upheld with costs. The High Court's finding that Advance Cleaning was liable was upheld and their appeal dismissed with costs.

Although Charter Hi and Chartaprops differ significantly on the facts both cases illustrate that common law developed sophisticated principles pertaining to vicarious liability. Those who consider outsourcing should be aware of the all-important primary distinction between these types of contracts and how it affected liability towards third parties who were not privy to the content of contracts between employers and employees or more likely between mandators and mandataries.

Even though these two cases do not once mention the phrase "responsible outsourcing", one sees in both instances that the outsourcers were not detached, passive or reckless in their outsourcing. The CAA issued a list of competent examiners who could be trusted to perform tests

wrongfulness (breach of legal duty) with the test for negligence. Our courts sometimes use the duty-of-care concept incorrectly as a synonym for the legal duty used to determine wrongfulness. To avoid confusion, it would be preferable to describe the duty involved in the .

67 Chartaprops 16 (Pty) Ltd v Silberman supra.

68 Par 46

69 Chartaprops 16 (Pty) Ltd v Silberman supra.

70 Par 46-47. 
according to their regulations and in the interests of flight safety. If there were evidence of the CAA's failure to ensure that flight inspectors were competent and specific evidence of the particular flight inspector's competency the fact that the flight inspector (Mr Grinstead) was not an employee of the CAA would not have excused the Minister. The basis would have been that the Minister should have foreseen that the particularly dangerous exercise of examining trainee pilots could cause damage if not overseen by a competent examiner and should furthermore have prevented the particular examiner from making his services available to members of the public. Even though there was no formal outsourcing agreement between the CAA and Grinstead the CAA's official notice enabled Grinstead to make his services available. This does amount to outsourcing in the widest sense of the word because the CAA cannot perform its duties without the assistance of flight examiners. Chartaprops on the other hand had a formal agreement with the cleaning service. One gathers from the evidence before the court that it was a critical consideration that Chartaprops contracted with a reputable cleaning service. The court also mentions Chartaprops's continued involvement in the operations of the cleaning service by liaising with them on a daily basis and by inspecting the work of the service.

It is submitted that the nature of the operation that is outsourced and the potential danger thereof will ultimately dictate the steps that should be taken by the outsourcer and the level of their continued involvement in the operation. In addition it is argued that Charter Hi and Chartaprops illustrate that failure to ensure that an outsourced function is performed properly may lead to liability where the outsourcer could reasonably foresee that the outsourcee's acts could cause harm, and the outsourcer failed to act in order to prevent the harm.

The next step is to consider the statutory framework, which applies to contracts of outsourcing and possibly to the content of such agreements.

\section{STATUTORY FRAMEWORK}

\section{Introduction}

Bhagattjee states that outsourcing is not specifically regulated in that there is no one, dedicated statute that stipulates how and when outsourcing should take place and where the responsibility for certain operations lies. ${ }^{71}$ As indicated above it is thus important for purposes of vicarious liability to determine whether a person is an employee or not. Some provisions of the LRA and the CPA as acts of general application provide some information on outsourcing of the risk from one entity/possible defendant to another. The Competition $\mathrm{Act}^{72}$ applies to outsourcing agreements when it involves the so-called restrictive horizontal and vertical practices as well as mergers. ${ }^{73}$ The Act applies especially when these practices result in the substantial

71 Bhagattjee "Country Q \& A South Africa" (2009) PLC Cross-border Outsourcing Handbook 2009175 www.practicallaw.com/6-384-9582 chapter (accessed 2013-03-20).

7289 of 1989.

$73 \mathrm{~S} 12$ of the Competition Act. 
lessening or the prevention of competition in a given market. In addition, it determines when a merger takes place as well as the provisions regarding a merger. However, the provisions of the Competition Act are not of general application, and regardless of whether mergers are small, intermediate or large, the outsourcing agreements that should be in place between different vendors or companies are aimed at preventing monopolistic situations and are not directly relevant to the present discussion on liability of outsourcers and outsourcees to third parties.

\section{Labour Relations Act}

\section{Transfer of business}

Section 197 and 197A of the LRA regulate the employment-related consequences of transfers of a whole or part of a business as a going concern. Section 197A regulates transfers of businesses in the case of insolvency whereas section 197 deals with transfers of business where the whole or part of a business transfers from one employer to another and the business is transferred as a going concern. ${ }^{74}$

It is thus important to look at the definitions of "transfer", "business" and "going concern" when dealing with section 197 and 197A. "Transfer" means "the transfer of a business by one employer ('the old employer') to another employer ('the new employer') as a going concern". ${ }^{75}$ It appears that two enquiries should occur when looking at transfers in terms of section 197: First, was there a transfer within the meaning of section 197 and, if so (on the facts), was there a transfer of an undertaking as a going concern? ${ }^{76}$ The concept of a transfer, it seems, relates to "the method' of the transfer of business". 77 Although most business transfers often occur when a sale of the business takes place the reach of section 197 "clearly extends beyond transfer effected in these circumstances" mergers, take-overs, restructuring, exchange of assets, ${ }^{79}$ a donation and the outsourcing of non-core functions of business activities. ${ }^{80}$ The transfer of a business as a going concern "may include the increasingly common practice of 'outsourcing' or 'contracting-out' [of] various services which previously formed part of the business".

74 See Schutte $v$ Powerplus Performance (Pty) Ltd [1999] 2 BLLR 169 (LC) the court held that determining whether a transfer as a going concern took place it was a matter of substance rather than form and that all factors that were indicative of a transfer had to be weighed against those that were not indicative because no single fact was conclusive itself (par 35).

75 S 197(1)(b) of the LRA.

76 Van Niekerk et al Law@work 328.

Ibid.

Van Niekerk et al Law@work 329.

79 See also Ndima $v$ Waverley Blankets Ltd [1999] 2 BLLR 169 (LC) where the court looked at the distinction between a transfer as a going concern and the physical transfer of assets and stated that with the former the business remained the same but only in different hands and the latter the assets changed hands and were transferred from one owner to the next to be used in whatever business of his choice.

80 Authors' own emphasis. Van Niekerk et al Law@work 329.

81 See Biggs 2009 Obiter 662. 
In this context the importance of the concept "business" must also be determined. "Business" means "the whole or any part of a business, trade or undertaking, or service". ${ }^{82}$ In SAMRU v Rand Airport Management Co Ltd ${ }^{83}$ the court had difficulty in applying the "economic entity" test that was developed by the European Court of Justice (ECJ). The ECJ developed the concept to mean "an organized grouping of persons and assets facilitating the exercise of an economic activity which pursues a specific objective". ${ }^{84}$ In Rand Airport the company decided to outsource some of its non-core gardening and security functions. The company informed SAMWU that its members would be retrenched after they initially had made an offer that the affected employees might apply for jobs with the proposed contractors. SAMWU approached the Labour Court for an interdict contending that section 197 applied and that the employees were not retrenched but that their contracts of employment were automatically transferred to the contractors because they were engaged on the same terms of service at the contractors to whom the services were outsourced. The court in Rand Airport held that the definition of "business" included a "service" and that the outsourcing of gardening and security functions to contractors constituted a "service" for the purposes of section 197. The court also held that these were businesses capable of being transferred in terms of section 197. Van Niekerk et $a P^{35}$ is op the opinion that the Rand Airport judgment can be criticized "for confusing form and substance - the relevant enquiry is into the existence or otherwise of a discrete economic entity". ${ }^{86}$

The last issue that needs clarification is what constitutes a "going concern". It appears that the statutory definitions do not clarify this concept and it was left to the courts again to determine whether a business had been transferred as a going concern in terms of section 197 of the LRA. ${ }^{87}$ It is clear that there is not transfer of a going concern in following two circumstances: First, where a purchase of shares has led to an acquisition of control in a company. It is thus clear that no change of identity of the employer took place because "the contract of employment remains

S 197(1)(a) of the LRA.

[2005] 3 BLLR 241 (LAC).

Van Niekerk et al Law@work 330.

Law@work31.

36 Ibid. They further add that "[t]his requires a court to enquire into the existence or otherwise of the variety of components that make up a business, amongst others the following: assets; goodwill; a workforce; management staff; the way in which its work is organised and performed; operational resources available to it; and so forth. To dismiss the necessity for this enquiry, as the court appears to have done, is to elevate a single component in the statutory definition of 'business' (a 'service') from an illustrative to a determinative level, and effectively to allow form to dictate substance. This is not to say that a 'service' can never be a business for the purposes of section 197. But in some circumstances at least, the whole or part of a business in the form of the provision of services might not meet the threshold requirements that ought to define a business. As the ECJ has acknowledged, this is often a difficult exercise when the business concerned is labour intensive and consists of little more than a group of employees dedicated to a common task. What is clear though is that a business entity cannot be said to consist solely of the activity being performed by it. A court ought to examine all of the relevant elements and components that comprise the business, and determine whether they are sufficiently linked and structured so as to comprise an economic entity capable of being transferred in terms of section 197."

87 Van Niekerk et al Law@work 331; as well as Biggs 2009 Obiter 659. 
unaffected by any change in the shareholding in the employer party to the contract." ${ }^{88}$ Secondly, where there is only a disposal of the assets of a business and no operating business is transferred. ${ }^{89}$ Van Niekerk et al points out that a transfer as a going concern is effected:

"when the economic entity that comprises the business retains its identity after the transfer. Typically, the identity of the entity that comprises a business, trade, undertaking or service comprises the employees themselves, the premises on which it is conducted, fixtures and fittings, stock, work-inprogress, contracts, book debts, brand names, trademarks and patents. In addition to these tangible assets, intangible assets such as goodwill can be added".

\section{Outsourcing}

Section 197 of the LRA "has been a source of confusion and concern" and has "given rise to such widely divergent interpretations" especially when it concerns the issue of outsourcing ${ }^{91}$ and now the controversial issue of "second-generation outsourcing". ${ }^{92}$ When due cognisance is taken of the principles relating to the definition of a transfer as going concern as well as business it has been "held to apply to transfers that occur when an employer decides to outsource a part of its activities to a service provider., ${ }^{93}$

Van Niekerk et al add that, although "it is generally accepted that section 197 will apply to most instances of outsourcing, the application of the section to 'second-generation' contracting was more contentious". ${ }^{44}$ Secondgeneration contracting "occurs when a new contractor (which may but not necessarily have been the service provider to whom a business function was initially outsourced) replaces the incumbent contractor" and "typically occurs when the terms on which the service provider, often a competitor of the incumbent contractor, is appointed to provide the service.",95 The authors further add that if the Labour Appeals Court's judgment in the Rand Airport case is correct, "there can be very little in the way of an outsourced function that will not fall within the ambit of $s$ 197.",96 The courts in recent cases of COSAWU $v$ Zikhethele (Pty) Ltd, ${ }^{97}$ Zikhethele (Pty) Ltd $v$ COSAWU ${ }^{98}$ and

Ibid.

89 Van Niekerk et al Law@work 332.

90 Ibid. Ngcobo J in NEHAWU v University of Cape Town 200324 ILJ 95 (CC), however, stressed that factors such as the transfer of tangible and intangible assets as well as transfer of workers and customers and whether the same business is carried on by the new employer should be considered when determining whether a transfer as going concern has taken place. He also stressed that the substance and the form of the transaction is of importance and that an overall assessment should take place.

91 See the definition of outsourcing and first-generation outsourcing in par 1 above.

92 Bosch "Aluta Continua, or Closing the Generation Gap: Section 197 of the LRA and its Application to Outsourcing" 2007 Obiter 84. Bosch also refers to Benjamin "A Matter if Ongoing Concern: Judicial Interpretation and Misinterpretation of Section 197 of the Labour Relations Act” 2005 Law, Democracy \& Development 169.

93 Van Niekerk et al Law@work 335.

94 Ibid.

95 Ibid.

96 Van Niekerk et al Law@work fn 41.

200526 ILJ 1056 (LC).

98200728 ILJ 2742 (LAC). 
Aviation Union of South Africa $v$ South African Airways (Pty) Ltd ${ }^{99}$ were faced with the contentious issue of whether section 197 of the LRA was applicable to second-generation outsourcing as well as whether a purposive approach should be applied when interpreting section 197. In the Zikhethele case the court held that "a compelling argument can be made, based on the express language in section 197 of the LRA, that the requirement in section $197(1)(b)$ that a transfer of business be by one employer to another precludes its application to second-generation contracting-out, because in such arrangements nothing is transferred by the old employer to the new employer". ${ }^{100}$ The court added that this thus entails that the application of section 197 is extended to second-generation contracting-out. The reasoning it seems is that the courts do not require a contractual link between the old and new employers for section 197 to apply to the transfer. The court was of the view that a purposive approach should be applied and thus employees affected by the second-generation outsourcing contracting out are deserving of protection as those affected by the first generation outsourcing contract. ${ }^{101}$ The court then added that section 197(1)(b) might be better interpreted to apply to 'transfers 'from' one employer to another, as opposed to only those effected 'by' the old employer"102 and thus a pragmatic interpretation entails that a transfer occurs in two phases: "in the first, the business is handed back to the outsourcer; and in the second, it is awarded to the new employer". ${ }^{103}$

This two-phase interpretation has been met with much criticism as it has been suggested that "all that transpires when a second-generation contract is concluded is the termination of one commercial contract and the commencement of a new contract, in other words that neither in fact nor in law is there any reversion to the client". ${ }^{104}$ Bosch is also of the view that if the section applies to second-generation outsourcing that the incoming contractor would have to take on the employees of the outgoing (incumbent) contractor on their existing terms and conditions, and that information sharing might be a problem here as the incumbent contractor will not willingly share information with the incoming contractor regarding remuneration and benefits its employees receive as it will also be competing for the same contract. ${ }^{105}$ Van Niekerk et al submit that section 197(1)(b) refers "to a transfer by one employer to another" and to read "this provision to mean (as the court did in Zikhethele) that section 197 applies when there is a transfer from one employer to another is not sustainable given the plain meaning of the words". ${ }^{106}$ They add that, if the application of section 197 is so limited, it will affect first-generation outsourcing, but not second and subsequent transfers. But when a literal meaning is applied the employees of the second transfer would have less protection than those in the first transfer and this would have "commercial ramifications" as the incoming

2012 (1) SA 321 (CC).

100 Par 29.

101 See Grogan and Gauntlett “Case Roundup: Double Transfer” 2005 EL 20.

102 Par 29.

103 COSAWU v Zikhethele (Pty) Ltd supra, Zikhethele (Pty) Ltd v COSAWU supra.

104 Van Niekerk et al Law@work 337.

105 Bosch 2007 Obiter 90.

106 Van Niekerk et al Law@work 337-338. 
contractor is in a much better position that the potentially outgoing contractor. $^{107}$ The incoming contractor (bidder) will thus not be bound by section 197 transfer provisions and can thus save employment-related costs that the first contractor could not avoid. The first contractor will also be liable for severance pay and statutory notice payments, and thus these consequences will not just be unsatisfactory for the outgoing contractor but also for the employees.

In the Aviation Union of South Africa case the court held that section 197 should be purposively interpreted and as a result potentially applies to second-generation outsourcing agreements. The majority stated that the substance rather than the form of the transaction is the determining factor. The substance of the initial transaction rather than the provision of an outsourced service remains significant during subsequent transfers. Thus, more specifically, it is relevant that what is outsourced is a going concern. ${ }^{109}$ If the outsourcing institution from the outset did not offer the service, that service cannot be said to be part of the business of the transferor because what happens here is simple contracting out of the service, nothing more, nothing less and therefore does not constitute a transfer of the business as a going concern. ${ }^{110}$ The outsourcee is contracted to provide the service, and becomes obliged to do and it becomes the outsourcee's responsibility to make appropriate business-infrastructure arrangements that may include the following: securing staff, letting appropriate property for office or other work space, and acquiring fixed assets, machinery and implements, computers, computer networks and the like. Cancellation of the contract in these circumstances entails only that the outsourcee forfeits the contractual right to provide the service, and thus the whole infrastructure for conducting the business of providing the outsourced service would ordinarily remain the property of the outsourcee. ${ }^{111}$ Van Niekerk et al points out that the courts have emphasized that "employers cannot rely on section 197 as a stratagem to transfer employees from its employee where there is no business being transferred or where the employer simply wishes to utilise the section to divest itself of ${ }^{112}$ a number of employees".

\section{The effect of a transfer of business}

The following consequences (unless otherwise agreed) can be attached to a transfer of a business in terms of section 197 of the LRA:

(a) the new employer is automatically substituted in the place of the old employer in respect of all contracts of employment in existence immediately before the date of transfer;

(b) all the rights and obligations between the old employer and an employee at the time of the transfer continue in force as if they had been rights and obligations between the new employer and the employee;

\footnotetext{
Van Niekerk et al Law@work 338.

Ibid.

Pars 106-107.

Aviation Union of South Africa (supra).

Ibid.

12 Van Niekerk et al Law@work340.
} 
(c) anything done before the transfer by or in relation to the old employer is considered to have been done by or in relation to the new employer and will include the following: the dismissal of an employee, the commission of an unfair labour practice and act of unfair discrimination;

(d) the transfer does not interrupt an employee's continuity of employment, and an employee's contract of employment continues with the new employer as if with the old employer.

The Aviation case (above) established that there was no reason in principle why section 197 of the LRA should not apply to outsourcing agreements and it would not matter whether it was a first-generation transfer or a second-generation transfer. The same test (meaning an objective test) should be applied to each transaction and should just be based on the unique facts and circumstances in that instance and should include an enquiry into the following:

"(1) the existence of a transfer by one employer to another, (2) whether there was a transfer of business (is there an economic entity capable of being transferred?) and (3) whether the business is transferred as a going concern (does the economic entity that is transferred retain its identity after the transfer?)."

The courts have also been of the view that no transfer of a business as a going concern for purposes of section 197 takes place only on account of where termination of a contract between the client and a service provider takes place and a new service to provide the same or a similar service is appointed. ${ }^{114}$ It must again be noted that, when an outsourcee is contracted to provide a service, and becomes obliged to do so in circumstances where it is the outsourcee's responsibility to make appropriate business infrastructure arrangements, and in particular, the securing of staff, the cancellation of such a contract entails only that the outsourcee's contractual right to provide the service terminates will be forfeited in circumstances in which the whole infrastructure for conducting the business of providing temporary labour will ordinarily remain the outsourcee's property. ${ }^{115}$ It should

113 See Franmann Services (Pty) Ltd v Simba (Pty) Ltd [2012] 12 BLLR 1293 (LC) par 7-8, where the court referred to the Aviation case. In casu The applicant (Franmann) sought an order declaring that on the termination of an agreement between it and Simba (the first respondent), the employment contracts of those of its employees currently engaged in providing services to Simba were transferred in terms of s 197 of the LRA to the second respondent (Capital Outsourcing) and alternatively any new service provider appointed by Simba. Both Franmann and Capital Outsourcing were temporary employment services (labour brokers). Since 2000, Franmann had supplied labour to Simba and the contract between them terminated on 31 August 2012. Simba then appointed Capital Outsourcing to provide it with temporary employment services.

114 Franmann Services (Pty) Ltd v Simba (Pty) Ltd supra par 17.

115 Par 17 where the court applied the Aviation case judgment to the facts. In PE Pack $4100 C C$ $v$ Sanders [2013] 4 BLLR 348 (LAC) the court was confronted with the issue of whether s 197 of the LRA apply to situations where a franchisor terminates its franchise agreement with the franchisee and replaces the franchisee with a new franchisee by entering into another franchise agreement. The court cautioned that great care must be taken before applying outsourcing jurisprudence to a franchise operation. The court noted that when new franchise agreement is concluded between the franchisor and the new franchisee it gives rise to the use of the assets being made available to the new franchisee as a quid pro quo or a franchise fee/share of the profits by the franchisor. The majority judgment (as per Davis JA and Hlophe AJA) is as follows: "In short, appellant had not acquired the business as a 
again be reiterated that not every cancellation of a service contract and the subsequent appointment of a new service provider will trigger the application of section 197 of the LRA and that each case should be considered by utilizing various tests. These tests are whether there is a transfer of business as a going concern and whether there was in fact an economic entity retaining its hands after the transfer. ${ }^{116}$

\section{Consumer Protection Act: Application and exclusionary clauses}

Already before the enactment of the CPA writers argued in favour of strict product liability. ${ }^{11}$

going concern from either third or fourth respondent. It cannot be said therefore that components of the business operated by third or fourth respondent had then been passed onto the appellant. What effectively had taken place was that the license to operate a business on behalf of second respondent had been terminated by the latter, in so far as third and fourth respondents were concerned. This was not the equivalent situation to that of an outsourcing agreement. The franchisor continued to hold the core assets. They remained those of the franchisor, being second respondent, both before and after the agreement had been concluded. There was thus no transfer of infrastructural assets which would sustain an argument that there was a transfer of a going concern. Once the core assets remained intact, that is in the ownership of the second respondent as the franchisor, it becomes difficult to see how a transfer of a business pursuant to $s$ 197(1) has taken place" (par 18). In his dissenting judgment, Landman AJA came to the following conclusion: "Was there a transfer from the old employer to the new employer? It could be said that there has been no such transfer because the franchisor does not intend operating the shop. The franchisor intends extending a franchise to a new franchisee. In this case, taking into account the nature and modus operandi of a franchise, it may be said that the franchisor intended to seamlessly transfer the operation of the shop to the new franchisee. The old franchisee knows that this will happen and so does the new franchisee. In these circumstances, there has been transfer of an undertaking, albeit an indirect one, from the old franchisee (old employer) to the new franchisee (new employer). The franchisor fulfils the role of a self-interested conduit being [sic] the old and new franchisees" (par 41). Please also take note of the fact that franchise agreements are governed by the CPA and fall outside the scope of this contribution. It is, however, important to take note of the definition of a franchise agreement. A franchise agreement is defined as "an agreement between two parties, being the franchisor and franchisee, respectively

(a) in which for consideration paid or to be paid, by the franchisee to the franchisor, the franchisor grants the franchisee the right to carry on business within all or a specific part of the Republic under a system or marketing plan substantially determined or controlled by the franchisor or an associate of the franchisor;

(b) under which the operation of the business of the franchisee will be substantially or materially associated with advertising schemes or programmes or one or more trademarks, commercial symbols or logos or any similar marketing, branding, labelling or devices, or any combination of such schemes, programmes or devices, that are conducted, owned, used or licensed by the franchisor or an associate of the franchisor; and

(c) that governs the business relationship between the franchisor and the franchisee, including the relationship between them in respect of goods or services to be supplied to the franchisee by or at the direction of the franchisor or an associate of the franchisor" (s 1 of the CPA).

116 Laubscher and Jefferson "Section 197 - Appointment of a New Service Provider" April 2013 De Rebus 58.

117 In the words of Van der Walt: "The recognition of strict liability in the case of products liability can be justified by various other factors: the public interest in the physicalpsychological well-being of human beings requires the highest measure of protection 
The CPA changes common law by introducing strict liability. In addition, it sets out "the basic rules of conduct that governs the interaction between businesses and consumers to ensure a fair and transparent market place."118 Parties to an outsourcing agreement should be aware to the provisions of the CPA as they may affect their liabilities towards third parties.

In order to establish if the CPA is applicable to outsourcing agreements one should consider the scope of application of the act. The CPA is applicable both to the provision of goods ${ }^{119}$ and services ${ }^{120}$ and therefore regulates all aspects of the purchasing cycle for these.

In addition to the all-important definitions of "goods" and services", "transaction" means -

"(a) in respect of a person acting in the ordinary course of business -

against defective consumer products; by marketing and advertising the manufacturer creates a belief in the minds of the public that his product is safe; strict liability serves as encouragement to take the utmost degree of care; the manufacturer is, from an economic perspective, the party most capable of absorbing and spreading the risk of damage by price increases and insurance" (Van der Walt "Die Deliktuele Aanspreeklikheid van die Vervaardiger vir Skade Berokken deur Middel van sy Defekte Produk" 1972 THRHR 254). See also Wagener v Pharmacare Ltd; Cuttings v Pharmacare Ltd 20034 SA 285 (SCA) 297,300 , where the court stated that at that moment no urgent grounds existed to apply strict product liability in South African law and referred the possible imposition of strict liability to the legislature: "[F]urther, as to the argument that strict liability had to be imposed for commercial reasons, that it was preferable that this should be done by legislation after due Parliamentary process and investigation so as to produce a comprehensive set of principles, rules and procedures. Single instances of litigation could not possibly provide for the depth and breadth of investigation, analysis and determination necessary to produce, for use across the manufacturing industry, a cohesive and effective structure by which to impose strict liability".

118 Draft Green Paper on the Consumer Policy Framework 09/04 24.

119 Goods includes: "(a) anything marketed for human consumption; (b) any tangible object not otherwise contemplated in aforesaid paragraph including any medium on which anything is or may be written or encoded; (c) any literature, music, photograph, motion picture, game, information, data, software, code or other intangible product written or encoded on any medium, or a licence to use any such intangible product; (d) a legal interest in land or any other immovable property, other than an interest that falls within the definition of "service" in this section; and (e) gas, water and electricity" ( 1 of the CPA).

120 Services include, but are not limited to "(a) any work or undertaking performed by one person for the direct or indirect benefit of another; (b) the provision of any education, information, advice or consultation, except advice that is subject to regulation in terms of the Financial Advisory and Intermediary Services Act 37 of 2002; (c) any banking services, or related or similar financial services, or the undertaking, underwriting or assumption of any risk by one person on behalf of another, except to the extent that any such service (i) constitutes advice or intermediary services that are subject to regulation in terms of the Financial Advisory and Intermediary Services Act, 2002 (Act 37 of 2002); (ii) or are regulated in terms of the Long-term Insurance Act, 1998 (Act 52 of 1998) or the Short-term Insurance Act, 1998 (Act 53 of 1998); (d) the transportation of an individual or any goods; (e) the provision of - (i) any accommodation or sustenance; (ii) any entertainment or similar intangible product or access to any such entertainment or intangible product; (iii) access to any electronic communication infrastructure; (iv) access, or of a right of access, to an event or to any premises, activity or facility; or (v) access to or use of any premises or other property in terms of a rental; ( $f$ ) a right of occupancy of, or power or privilege over or in connection with, any land or other immovable property, other than in terms of a rental; and (g) rights of a franchisee in terms of a franchise agreement to the extent applicable in terms of section $5(6)(b)$ to $(e)$, irrespective of whether the person who promotes, offers or supplies the services participates directly in the services or supervises it or is directly or indirectly involved therein" ( 1 of the CPA). 
(i) an agreement between or among that person and one or more other persons for the supply or potential supply of any goods or services in exchange for consideration; or

(ii) the supply by that person of any goods to or at the direction of a consumer for consideration; or

(iii) the performance by, or at the direction of, that person of any services for or at the direction of a consumer for consideration; or

(b) an interaction contemplated in section 5(6), irrespective of whether it falls within paragraph (a)."

Accordingly the definitions of goods and service in the CPA also apply to outsourcing agreements for products and services. ${ }^{122}$ If the CPA applies to any products and services that form the subject of an outsourcing agreement the CPA also applies to the outsourcing of these products and services. ${ }^{123}$ It follows that the CPA regulates, amongst other issues, such as marketing activities and administration of the outsourcing relationship, the terms and conditions thereof, the delivery of the goods and services, the quality of goods and services as well as service levels, warranties, indemnities, liability (including product liability) and dispute resolution. ${ }^{124}$ Therefore, if the operations of shopping Centre A in our initial example or even Chartaprops fall within the ambit of the CPA, outsourcing of a particular function will not cause the outsourcer to escape liability. Rather, the outsourcer and outsourcee remain strictly liable for damage to third parties. Closely related to the definitions already mentioned are the exclusions.

Grealy and Coelho are of the view, that in addition to other exceptions, the CPA does not apply to agreements (in terms of which goods and services

$121 \mathrm{~S} 1$ of the CPA. The following arrangements must be regarded deemed to be a transaction for purposes of section $5(6)(a)$ to (e): (i) The supply of any goods or services in the ordinary course of business to any of its members by a club, trade union, association, society or other collectivity, whether corporate or unincorporated, of persons voluntarily associated and organized for a common purpose or purposes, whether for fair value consideration or otherwise, irrespective of whether there is a charge or economic contribution demanded or expected in order to become or remain a member of that entity; (ii) a solicitation of offers to enter into a franchise agreement; (iii) an offer by a potential franchisor to enter into a franchise agreement with a potential franchisee; (iv) a franchise agreement or an agreement supplementary to a franchise agreement; and (v) the supply of any goods or services to a franchisee in terms of a franchise agreement.

122 Grealy and Coelho "Outsourcing: South Africa Overview" (2012) http://commercial.practical law.com/7-505-4428 (accessed 2013-04-04).

123 Grealy and Coelho 2 (see fn 122 above).

124 Grealy and Coelho 2-3 (see fn 122 above).

125 The CPA does not apply to any transaction:

(i) in terms of which goods and services are promoted or supplied to the State;

(ii) in terms of which the consumer is a juristic person whose asset value or annual turnover, at the time of the agreement, is equal to or exceeds R2 million;

(iii) if the transaction falls within an industry-wide exemption granted by the Minister to a particular industry;

(iv) that constitutes a credit agreement under the National Credit Act 34 of 2005, but the goods and services that are the subject of the credit agreement are not excluded from the ambit of the Act;

(v) pertaining to services to be supplied under an employment contract;

(vi) giving effect to a collective bargaining agreement within the meaning of section 23 of the Constitution 1996 and the LRA; or

(vii) giving effect to a collective agreement as defined in section 213 of the LRA (See S 5(2) of the CPA). 
are promoted or supplied to the State and in terms of which the consumer is a juristic person whose asset value or annual turnover, at the time of the agreement, is equal to or exceeds R2 million), and that most outsourcing agreements therefore pertain to these two exceptions. ${ }^{126}$ They add that any supplier should assess "whether the customer is entitled to the protections of the CPA and whether the CPA applies to the transaction (particularly where the consumer is a sole-proprietor or a new company)". ${ }^{12}$

The CPA is of cardinal importance as far as liability to third parties is concerned as this act introduces strict product liability. In terms of section 61 of the CPA, a producer, importer, distributor or retailer of goods will be liable for defective products. These categories of persons are liable jointly and severally. ${ }^{128}$ They are also liable wholly or partly for supplying any unsafe goods, product failure, defect or hazard in any goods or inadequate instructions or warnings provided to the consumer pertaining to any hazard arising from or associated with the use of any goods. ${ }^{129}$ Liability arises irrespective of whether the harm resulted from any negligence on the part of the producer, importer, distributor or retailer, as the case may be. ${ }^{130}$

Section 61 applies only where services are outsourced because a "supplier of services who, in conjunction with the performance of those services, applies, supplies, installs or provides access to any goods, must be regarded as a supplier of those goods to the consumer ....131 Both the outsourcer and the the outsourcee can be held jointly and severally liable where services are provided in terms of an outsource agreement. Again consider the facts of Chartaprops. This case was decided before the introduction of the CPA and Chartaprops escaped liability because of their meticulous monitoring of the activities of Advanced Cleaning. This would not have been possible had the CPA applied to the situation. However, if the agreement fell outside the scope of the CPA either because of the exceptions or a defence forwarded by the shopping centre, Chartaprops would still be good law.

${ }^{26}$ Grealy and Coelho 3 (see fn 122 above).

Ibid.

S 61(3) of the CPA.

S 61(4) of the CPA.

130 S 61(4), however, contains the following defences: "Liability of a particular person in terms of this section does not arise if - (a) the unsafe product characteristic, failure, defect or hazard that results in harm is wholly attributable to compliance with any public regulation; (b) the alleged unsafe product characteristic, failure, defect or hazard - (i) did not exist in the goods at the time it was supplied by that person to another person alleged to be liable; or (ii) was wholly attributable to compliance by that person with instructions provided by the person who supplied the goods to that person, in which case subparagraph does not apply; (c) it is unreasonable to expect the distributor or retailer to have discovered the unsafe product characteristic, failure, defect or hazard, having regard to that person's role in marketing the goods to consumers; or (d) the claim for damages is brought more than three years after the - (i) death or injury of a person contemplated in subsection (5)(a); (ii) earliest time at which a person had knowledge of the material facts about an illness contemplated in subsection (5)(b); or (iii) earliest time at which a person with an interest in any property had knowledge of the material facts about the loss or damage to that property contemplated in subsection (5)(c); or (iv) the latest date on which a person suffered any economic loss contemplated in subsection (5)(d)."

131 S 61(2) of the CPA. 
The importance of the CPA lies therein that it is not possible to shift the blame for a portion of the production chain or service by outsourcing it. If the Act applies, it applies to the outsourcer and outsourcee alike and they are jointly and severally liable towards clients.

Another way in which parties avoid liability is where they agree not to litigate against each other in the event of loss. Such agreements are usually manifested in exclusionary clauses or disclaimers. At common law, disclaimers are allowed if these form part of a valid agreement and both parties were aware of the content for the particular clauses. ${ }^{132}$ A so-called pactum de non petendo in anticipando in a contract does not exclude wrongfulness or fault but it does exclude the action itself. ${ }^{133}$ This means that parties agree that even though a delict has been committed, the victim may not sue the wrongdoer. ${ }^{134}$ The operation of a clause depends on the interpretation of the clause. In general, disclaimers exclude ordinary negligence. If parties want to exclude gross negligence, they should do so explicitly. It is, however, not possible to exclude intentional conduct in a disclaimer. Where parties agreed that, where one of the parties' intentional conduct will not form the basis of an action for the other's damages, that agreement is unlawful and will not be enforced. In addition, disclaimers do not operate against the dependants of those who agreed to the original disclaimer. ${ }^{13}$ These are the common-law principles regarding disclaimers. Note that if the CPA is applicable to an agreement it is still possible to include a disclaimer. However, this Act states that any notice or provision of a consumer agreement which limits in any way the risk or liability of the supplier or any other person must be written in plain language ${ }^{136}$ In addition, section 49(4) stipulates as that the disclaimer should comply with the following requirements:

"The fact, nature and effect of the provision or notice contemplated in subsection (1) must be drawn to the attention of the consumer -

(a) in a conspicuous manner and form that is likely to attract the attention of an ordinarily alert consumer, having regard to the circumstances; and

(b) before the earlier of the time at which the consumer -

(i) enters into the transaction or agreement, begins to engage in the activity, or enters or gains access to the facility; or

(ii) is required or expected to offer consideration for the transaction or agreement."

Finally, the consumer must be given an adequate opportunity in the circumstances to receive and comprehend the disclaimer. ${ }^{137}$ In the example of the shopping mall one can envisage that a disclaimer printed on the back of a parking ticket does not comply with section 49(4) of the CPA and can therefore not be enforced against a party who suffered damages. Therefore, when drafting an outsourcing agreement that includes disclaimers of any

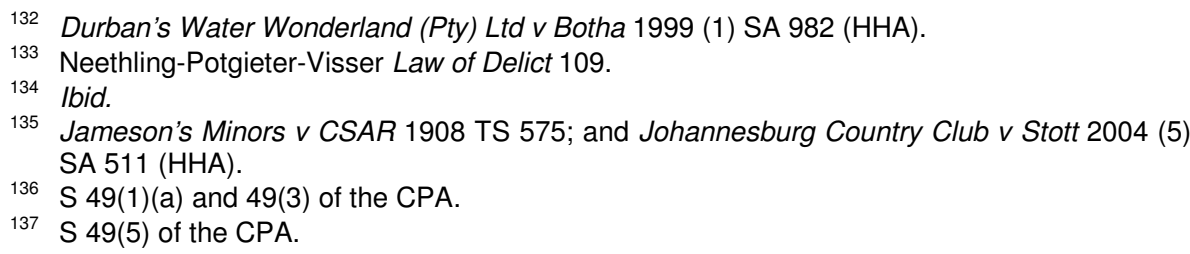


kind, the drafter must ensure that the disclaimer complies with the commonlaw or statutory framework that is applicable to that particular contract.

\section{$4 \quad$ LIABILITY INSURANCE}

Liabilities to the outsourcing of services generally relate to any damage to or destruction of property, death or injury of any person, breaches of confidentiality, breaches of certain warranties, actual or alleged infringement of rights (including intellectual property infringements) as well as claims by any third party (including claims by employees of either party). ${ }^{138}$ In South Africa liability insurance is regulated by the Short-term Insurance Act. ${ }^{139}$ Accordingly, "liability policy" denotes a contract in terms of which a person, in return for a premium, undertakes to provide policy benefits if an event relating to the incurring of a liability occurs. ${ }^{140}$ Generally speaking, the liability insured against must be described in the policy. ${ }^{141}$ It is therefore always advisable to consider all possible liabilities and to procure appropriate cover. However, it should be borne in mind that if the policyholder would not have been liable in the first instance, the insurer will also not be liable. For example: The owners of the shopping mall $A$ requested shoppers not to park in the area right in front of the mall's entrance because this area was dedicated to delivery vehicles. The particular notice was printed in huge, red letters and was clearly visible. The notice further stated that owners who parked in this particular, delineated area did so at their own risk and that the mall would not be held responsible for any loss or damaged caused to any vehicle whilst parked in this area. Shopper $F$ disregarded this warning. A delivery vehicle parked next to her car and employees of the mall started to download heavy crates filled with merchandise. One of these employees underestimated the weight of the crate he was carrying. $\mathrm{He}$ tripped and fell and in the process dropped the crate onto F's vehicle, causing considerable damage to it. The insurance company with whom the mall held a liability policy would no doubt investigate the incident and if it transpired that the mall's owners would not be liable to $F$, it followed that the insurance company also had no obligation to indemnify F. ${ }^{142}$

Indemnity insurers often include exclusionary clauses in the policy. ${ }^{143}$ For instance, an insurer may refuse to honour a claim where the insured failed to

${ }^{138}$ Grealy and Coelho (122) 10 (see fn 122 above).

13953 of 1998.

140 S 1(1) of the STIA, sv "liability policy."

141 Reinecke, Van der Merwe, Van Niekerk and Havenga General Principles of Insurance Law (2002) 428.

142 An insured generally has a duty to disclose the nature and extent of the risk to the insurer. Failure to do so may lead to the insurer avoiding liability. See Van Niekerk "The Insured's Duties of Disclosure: Delictual and Contractual; Before the Conclusion and During the Currency of the Insurance Contract: Bruwer v Nova Risk Partners Ltd' 2011 SA Merc LJ 135.

143 See Reinecke "Remedies for Misrepresentation including a Long-Term Insurance Contract: The Didcott Principle" 2009 SA Merc LJ 387-395. The author states: "Non-disclosure entails a failure to speak where there is a duty to speak, while a misrepresentation by positive conduct occurs if a person creates by his conduct a wrong impression relating to a past or present fact, for instance, a wrong answer to a question in the proposal for 
adhere to safety requirements or to comply with a statute that has specific bearing on the risk. A shopping mall will for instance have to demonstrate that all subcontractors on the premises have been sourced in a responsible way.

\section{INDUSTRY-SPECIFIC EXAMPLES}

\section{General}

In certain industries, dedicated legislation contains rules pertaining to outsourcing. Bhagattjee mentions the financial services industry, the telecommunications industry and the public sector as three examples of where legislation regulates outsourcing to a certain extent. ${ }^{144}$ Against the background of the distinction between the contract of mandate and an employment contract and the LRA and CPA as statutes of general application, parties to an outsourcing agreement should finally consider industry-specific legislation when they enter into an agreement. The examples below are by no means exhaustive and only serve as examples of how outsourcing can be regulated in a specific industry.

\section{The Aviation Industry}

Charter $\mathrm{Hi}$ above demonstrates that the Minister of Transport as the accountable institution for civil aviation in South Africa outsourced the functions of flight inspectors for operational reasons. The Civil Aviation Authority ("CAA") no longer had the resources to keep flight inspectors on their payroll as permanent employees. One has to agree with this particular practice. Even though flight inspectors undeniably play a key role in the licensing of pilots for various licences and the CAA cannot issue licences without the input of flight inspectors it still makes sense to issue a list of approved inspectors for each province in South Africa and to decree that those inspectors' reports are acceptable to the CAA. The inspectors are independent contractors, but the difference is that the CAA still has the authority to remove a flight inspector from their list. Remember, flight inspectors also need to comply with the applicable stipulations in the Aviation Act ${ }^{145}$ and must for instance also renew their own licences from time to time. Failure to comply with these stipulations will automatically cause the CAA to remove the flight inspector from the list. Though these inspectors do not operate under the direct control of the CAA in the same way employees do, the CAA retains control because of aviation legislation. In this context responsible outsourcing of a function such as that of a flight inspector is highly unlikely. However, if the CAA fails to remove a non-compliant flight inspector from their list, the Minister of Transport will be liable for loss or damage to third parties, provided that all the elements of a delict are

insurance. It may be appropriate, if not customary, to refer to a positive misrepresentation as a mis-disclosure."

144 Bhagattjee 175 (see fn 71 above).

14574 of 1962 . 
present. The basis of such an action is therefore not vicarious liability but direct liability. ${ }^{146}$

\section{The Financial Services Industry}

Banks that outsource operations to a third party have a duty to notify the South African Reserve Bank (SARB) of any outsourcing arrangements that have a bearing on the risk profile of the banks, that affect the systems and controls of banks and have implications for the Reserve Bank's supervisory responsibilities. ${ }^{147}$ In addition, the Reserve Bank should also be notified of the outsourcing of any functions that are classified by a bank's management of being of strategic importance as well as outsourcing agreements that may have implications on the discharge of the duties under the supervisory processes followed by the Reserve Bank. ${ }^{148}$

Before outsourcing can take place, the bank which wants to outsource must "investigate the competence of the proposed supplier and verify the supplier's ability to perform at the required service levels for the duration of the agreement.."149 Furthermore, there is a duty on the bank to put in place appropriate structures to ensure the "ongoing management and monitoring of the terms of the outsourcing arrangement." ${ }^{150}$ Banks must also have rigorous service-level agreements in place that allow for early cancellation by the bank and formal contingency plans must be in place, supposedly for in case the service-level agreement is terminated prematurely. ${ }^{151}$ The purpose of these arrangements is to ensure that the Reserve Bank is at all times in a position to access information that would enable them to perform its regulator duties. Banks are not allowed to outsource their internal audit function to a third party. ${ }^{12}$

One gathers from the rules pertaining to outsourcing in the banking sector that it is not possible for a bank to compromise the integrity of the banking industry and to thwart the Reserve Bank's supervisory function by shifting the responsibility and possibly the blame to a contractor. Strict rules pertaining to outsourcing effectively make the subcontractor's services subject to the same rules that apply to the bank. There is no escaping liability and should a liability issue arise, the contract between the parties and the legislative structure in terms of which the bank operates will most likely indicate who the responsible party or parties are. There is not much of a difference between the bank's situation and that of the CAA.

\footnotetext{
146 See Botha and Millard "The Past, Present and Future of Vicarious Liability in South Africa 2012 De Jure 225.

147 SARB Guidance Note 3/2008. The Guidance Note was published in terms of s 6(5) of the Banks Act 94 of 1991

148 Ibid.

149 Bhagattjee 175 (see fn 71 above).

150 lbid.

151 lbid.

152 Ibid.
} 


\section{The Public Sector}

Outsourcing in the public sector was recently the topic of a heated debate. ${ }^{153}$ Problems range from consultants' appointments not being properly authorized to consultants being overpaid. Under the Constitution all government procurement must be "fair, equitable, transparent, competitive and cost-effective". ${ }^{154}$ Apart from the Constitution, statutes that regulate outsourcing in the public sector include the Public Finance Management Act, ${ }_{155}$ the Municipal Systems Act, ${ }^{156}$ the Municipal Finance Management Act, ${ }^{157}$ the Broad Based Black Economic Empowerment Act, ${ }^{98}$ the Promotion of Administrative Justice $\mathrm{Act}^{159}$ and the Preferential Procurement Policy Framework Act. ${ }^{160}$

\section{Telecommunications}

Although there are no regulations that deal specifically with telecommunications outsourcing, the supplier must comply with any relevant aspects of the telecommunications laws and regulations, which include that the supplier needs to be appropriately licensed and must, depending on the service rendered, comply with telecommunications regulations. ${ }^{161}$ In terms of $s$ 5(2) and 5(4) of the Electronic Communications Act the Independent Communications Authority of South Africa (ICASA) grant electronic communications-network services licences as well as electronic communications-services licences. Thus any of the services that will be provided under an outsourcing agreement in terms of $s 5(2)$ and 5(4) must obtain all the relevant licences and/or approvals from ICASA. This is in fact similar to the position of the flight inspector in Charter Hi.

$153 \mathrm{http}: / /$ www.info.gov.za/speech/DynamicAction?pageid=461\&sid=33855\&tid=97046; Genera/ Report on National Audit Outcomes 2010-11 www.agsa.co.za (accessed 2013-03-27).

154 Bhagattjee 175 (see fn 71 above); and Grealy and Coelho 10 (see fn 122 above).

155 Act 1 of 1999. The PFMA aims to ensure transparency, accountability and sound management of government finances. It also specifies the fiduciary duties and general responsibilities of governing bodies, heads of departments, accounting officers, managers and employees of boards or the accounting authorities, and provides for personal liability where legislative duties are breached. Outsourcing by any national and provincial government departments, State-owned or State-controlled entities "may require approval under the PFMA and any transaction concluded without the required approval is not enforceable against the particular state-owned entity or government department" (Grealy and Coelho 10 (see fn 122 above)).

15632 of 2000 .

15756 of 2003.

15853 of 2003. Black economic empowerment must be taken into account in any outsourcing transaction in the public sector and all public entities must comply with procurement processes that take into account the black economic empowerment status of the counterparty to the transaction (Grealy and Coelho 10 (see fn 122 above)).

1593 of 2000 .

1605 of 2000. This act is a critical component of black economic empowerment as it encourages procurement from historically disadvantaged individuals. It applies to all organs of State and establishes a detailed regulatory framework for which procurement policies must be implemented (Grealy and Coelho 10 (see fn 122 above)).

161 Bhagattjee 175 (see fn 71 above); Grealy and Coelho 4 (see fn 122 above); and s 7 of the Electronic Communications Act 36 of 2005. 


\section{RECOMMENDATIONS AND CONCLUDING REMARKS}

Modern-day commerce forces services providers to specialize and to channel more capital into their core functions. Non-core functions are increasingly outsourced.

Regardless of whether outsourcing is used for bona fide reasons such as to provide a better product at a better price or whether the outsourcer needs to dispose of troublesome employees or to limit his liabilities towards third parties, it is suggested that outsourcers should consider a number of issues when outsourcing. Conversely, in considering a liability issue, a court may also measure the conduct of a particular outsourcer in order to evaluate whether such outsourcer has acted bona fide and responsibly. An outsourcer should first consider whether the contract entered into is a true contract of work or whether it may in fact still be construed as an employment contract. As was explained, these have different consequences and vicarious liability is possible only where an employment contract exists. The law will give effect to the true intention of the parties, and where an employment contract is in fact presented as a contract of work, the outsourcer will not escape liability where an employee commits a delict. A second consideration in outsourcing from a liability point of view is whether the LRA applies where outsourcing involves the transfer or part-transfer of a going concern. The stipulations of the LRA in this regard make it possible to establish at any given time during the transfer who will be regarded as the de facto employer and who will be liable for the wrongful, culpable actions of employees.

A further consideration are the stipulations of the CPA. If the CPA applies to the activities of the outsourcer, any outsourced functions will also be governed by the CPA. The outsourcer and outsourcee will be strictly liable, jointly and severally, towards an injured third party.

If specific legislation exists that regulates the outsourcer's operation, such legislation should be scrutinized in order to establish whether any particular functions may be outsourced at all and if it is allowed, which specific stipulations should be complied with. The brief discussion on the banking sector illustrates for instance that it is crucial to exercise control over an outsourced function in order to ensure compliance in the best interest of clients.

In the absence of detailed, dedicated legislation such as the Banks Act ${ }^{162}$ it is submitted that there are compelling reasons to argue that an outsourcee will not escape liability where such agreement was entered into for mala fide purposes and without consideration of the consequences to third parties. In Chartaprops the court scrutinized the behaviour of the appellant and stated very clearly that it was the continued monitoring of the outsourcee and the sourcing of a reputable contractor that caused the appellant to escape liability towards the injured respondent. Therefore, irrespective of whether there are statutory obligations, where an outsourcer could have foreseen

16294 of 1991. 
that his outsourcing agreement could cause harm to a third party, and also if the harm could have been prevented by either not contracting with the outsourcee or by closely monitoring the activities of the outsourcee, the outsourcer will not escape liability.

Responsible outsourcing should be encouraged. South African law on the subject is not contained in one dedicated statute and it is also not necessary to enact new legislation. From a liability point of view our legal system is sufficiently equipped to deal with the results of harm caused to third parties. Finally, disclaimers, liability insurance and simulated contracts designed to shift the blame and to pass the buck from one potential defendant to another may not have the desired results. Sound legal advice should be sought before outsourcing is considered in order to avoid these pitfalls. 